\title{
Speech acts: the communicative revolution in language teaching
}

R. Blunt

In the last two decades, both the Theory of Speech Acts and its application have been extensive. The theory has been exploited particularly in the field of Applied Linguistics. The purpose of the writer is to indicate the value of the concept, to explain why it needs close analysis, to outline the theoretical constructions formulated to enable Applied Linguists to exploit the concept, and to describe some of the problems which arise from the application of the theory.

Gedurende die afgelope twee dekades het beide die Teorie van Spraakhandelinge en die toepassing daarvan uitgebrei. Die teorie is veral op die gebied van Toegepaste Linguistiek benut. Die doelstelling van die skrywer is om te wys op die waarde van die konsep en te verduidelik waarom intensiewe ontleding nodig is. Die skrywer omskryf ook die teoretiese strukture wat geformuleer is om toegepaste taalkundiges in staat te stel om die konsep te benut, asook sommige probleme wat uit die toepassing van die teorie spruit.

\section{THE VALUE OF THE CONCEPT "SPEECH ACT"}

Until quite recently, the main emphasis in teaching and learning a new language was on the cognitive element expressed through propositions such as:

The Romans were slain by the arrows of the barbarians.

The food was taken from the table by a slave.

It was assumed that, because this approach enabled the learner to decode literary classics, it was an adequate method for learning a language (the grammar-translation method).

J.L. Austin pointed out that this kind of utterance was but one of a long list of purposes or functions for which language is used. When someone utters something, it is normally done with an intention to do something by means of the utterance, or to "act" through "speech". For example, when one says:

"I will come and see you tomorrow", one is promising;

"I think you will pass your exams", one is declaring one's belief about something;

"Go to the end of the street", one is commanding, or instructing;

"That was a good job that you did", one is congratulating.

People learn a new language in order to do things, (perform speech acts) by means of it, and instead of learning all the sentence structures, vocabulary, idioms, and so on of a language, it is much more efficient (quicker and more appropriate, with less wasted effort) for a second language learner to learn to perform only those speech acts which are needed for his or her particular purposes.

For example, a person who wanted to work as a waiter in a restaurant, would need to be able to greet new customers, guide them to a table, request them to give their order, advise about the best food to choose, and many other things such as thanking, confirming, describing, apologising, etc. 
Therefore, it is not necessary for such a person to learn the whole language, but oniy to perform those speech acts appropriate to his or her needs. This has given rise to what is known as the functional curriculum in second or foreign language learning.

The problem with such a functional curriculum lies in identifying the communicative needs of the learner. The speech acts themselves must be identified, but in addition there are often several ways of performing them. For example, consider some of the common ways of warning someone against doing something:

I warn you against going there. (explicit warning)

Don't go there! (literally, a command)

I wouldn't go there if I were you. (literally, a prediction)

Going there isn't a good idea. (literally, opinioning, judging)

Why go there (of all places)? (literally, a question)

You're not going there, are you? (a tag-question inviting a denial)

It's stupid to go there. (literally, opinioning, evaluating or judging).

Or, to return to our example of a waiter, we might teach what is meant by the question, "Waiter, what do you recommend?" But the first customer to ask for a recommendation is just as likely to say, "What's good?" or "How is your fish?".

\section{THE NEED FOR AN ANALYSIS OF SPEECH ACTS}

The immediate need for a teacher to provide for all eventualities in the pupil's communicative environment demands research into the speech acts which the pupil will need to perform and understand. Lesson preparation for teachers of the functional language curriculum is, therefore, a matter of identifying relevant speech acts for pupils' needs, together with their appropriate realizations.

However, in order to develop anything approaching a formal curriculum, the educationalist requires an analysis of speech acts covering all communicative events, against which progress and objectives can be measured. How can speech acts be analysed?

Austin (1962) offered a first step by pointing out two different ways in which speech acts are performed, which result in distinctively different lists of speech acts.

The first type, and by far the most common and important for language and for teaching purposes, are speech acts which are performed "by uttering the right, explicit performative sentences", (Akmajian, 1979). In other words, you say what you mean. For example:

I order you to leave. (Speech Act: commanding)

I promise to come. (Speech Act: promising)

I appoint you chairman. (Speech Act: pronouncing)

These, Austin called illocutionary acts. An illocutionary act is performed in uttering it. It is the speaker's intention of how he or she wishes the utterance to be taken (as a command, promise, etc.). An illocutionary act does not depend on the listener or receiver to be successful. Even if the listener misinterprets the speaker's intention, the illocutionary act will have been successful if the intention has been performed by uttering the right explicit performative sentence. Verbs which perform explicit illocutionary acts are called performative verbs.

The second type he called perlocutionary acts. These are not performed by uttering the right explicit performative sentence. Rather they are achieved by means of illocutionary acts, but their effect is not that of the illocutionary act. 
For example, the illocutionary act of stating, "This soap is made from pure vegetable oils", has the perlocutionary effect of persuading. Or the illocutionary act of warning, "If you don't do your reading, you will fail your exams", has the perlocutionary effect of intimidating.

Notice that perlocutionary acts have the force but not the form of the illocutionary act. Therefore, perlocutionary acts are said to have illocutionary force.

Perlocutionary acts involve both the intentions of the speaker and their effects on the thoughts, feelings and actions of the hearer, by means of the speech act. The illocutionary act is performed in uttering something, whereas the perlocutionary act is performed by uttering something. Examples of perlocutionary acts are: intimidating, persuading, deceiving, irritating, impressing, inspiring, and embarrassing.

The following dialogue will be used to exemplify the distinction between illocutionary and perlocutionary acts. Notice that the reader is forced to search for clues to construct a context which will explain the waiter's behaviour.

Waiter: Good evening, sir. Welcome to the restaurant. Please take table number twenty in the corner. (The man sits down and the waiter approaches with the menu.)

Customer: What do you recommend?

Waiter: I recommend the chicken, sir.

Customer: No, I think I would like a steak.

Waiter: J recommend the chicken, sir. It has a delicious sauce.

Customer: I want steak. I don't want chicken.

Waiter: The chef's recommendation is the chicken, sir.

Customer: Are you deaf? I said I want steak.

Waiter: I warn you that the steak is a little off, sir.

Customer: Oh, I see. All right, bring me your chicken.

In reading this dialogue, we are able to predict a context for the waiter's behaviour, namely, that he/she was trying to avoid the embarrassment of admitting that the restaurant could not provide a steak by performing, insistently, the speech act of recommending. This is an illocutionary act, and the waiter was using it in an attempt to perform the perlocutionary act of persuading. However, the waiter was not successful, and eventually resorted to another illocutionary act, this time warning the customer against the steak. This resulted in the perlocutionary act being realized, and the customer was persuaded to order the chicken.

Notice that, even if the waiter had said, "I am persuading you to choose the chicken", the customer might not have been persuaded. It was only by means of the illocutionary act of warning that the perlocutionary act was performed.

This distinction is of less interest to the language teacher than to the philosopher. Consider, for instance, the philosophical problem of whether the act of teaching is illocutionary or perlocutionary. If it is perlocutionary, then this entails important considerations about the teacher's responsibility for ensuring that what the teacher intends the pupil to learn is learned.

The language teacher who intends his pupils to communicate in a language must teach them to do things with the language, or to perform speech acts. To do this, an analysis of speech acts according to criteria will enable the teacher to identify realizations of speech acts which will be most valuable for the needs of the pupils. Two major contributions to this problem have been made. The first, by Austin, has been developed further by several linguists, and the second is by Del Hymes. 


\section{CLASSIFICATION OF SPEECH ACTS}

Hymes (1968) classified speech acts according to their focus in the communicative event. He identified several factors in communication and showed that speech acts usually focus on one of these, resulting in six groups of speech functions. Such groups are called "macro functions".

Communication involves, firstly, the speaker, and any speech act which expresses the speaker's attitudes towards things would focus on the speaker as a person. These speech acts would include opining, judging, believing and intending. They have a personal function.

Secondly, communication involves a hearer. Speech acts which focus on the hearer would be those which are directive, such as commanding, suggesting, warning and permitting. They have a directive function.

Thirdly, the speaker and hearer need to create contact in order to communicate, and this would require speech acts which call a hearer's attention (greetings, etc.), solicit their continuing attention ("Do you follow?"), keep the conversation going through "small talk", and signpost the conversation (listing points, defining terms, giving examples). These speech acts are said to have a phatic function.

Fourthly, speech acts which focus on the rules of a particular linguistic code (such as the defining function in the scientific code) have what is termed a metalinguistic function.

Fifthly, those speech acts which focus on the topic of the utterance, and/or on its setting in place and time, have a referential function. This function was seized on by the old grammar-translation method of language teaching as being most appropriate to understanding the literature of the language.

Sixthly, speech acts which focus on the form of the message, its volume, tone or presentation, have what is termed an imaginative function. The term imaginative is used in the sense of oral or written composing, whereby the style of the composition conveys a rhetorical message in addition to its propositional content.

Each of these functions of speech can be signalled by the speaker in order to warn the hearer about his or her intentions of how the utterance is to be taken. These signals are called "function indicating devices". So the personal function may be indicated by saying "In my opinion . . .", or "I think . . .", and the directive function may be signalled by the form of a question or command, preceeded in the polite form by the modals would or could, as in "Would you help me carry these books?".

Austin's classification (1962), by contrast, attempted to categorise the communicative intentions behind utterances. His analysis has since been extensively modified and revised, particularly by Van Ek, Wilkins and Munby, and it is Munby's version which I will outline in order to give a recent categorisation of the functional uses of language. There are seven groups of functions, also termed macro-functions:

The first group is a scale of certainty, which includes speech acts expressing degrees of personal certainty (I am certain, I think, I doubt, I am not certain), and impersonal certainty (he is sure to pass, he should pass, he may pass, he is certain not to pass).

The second is a scale of commitment including speech acts expressing intention (I want/prefer/promise ...), and obligation (it is my duty/responsibility).

The third group includes speech acts expressing judgement and evaluation, including valuation (I estimate it is worth ...), verdiction (I condemn/sentence/forgive you), approval (I commend/appreciate your concern) and disapproval (I deplore your ingratitude).

The fourth group expresses suasion, including inducement (I suggest/advise ...), compulsion (I command/prohibit ...), prediction (I warn/invite/threaten ...), and tolerance (I consent/agree to/ authorise . . .). 
The fifth expresses argument, stating or asserting information, seeking information and denying information (I reject/oppose your point . . .), expressing agreement, disagreement (I wouldn't go along with that point) or concession.

The sixth group expresses rational enquiry and exposition, and includes stating presuppositions, hypotheses, substantiating, generalising, concluding, interpreting, explaining, demonstrating, classifying, defining and exemplifying.

The seventh and final group expresses formulaic communication such as greeting, farewells, thanking, apologising, congratulating, commiserating, and saying things which show that you are paying attention.

Hymes' analysis gives more attention to the interpersonal, metalinguistic and imaginative functions of language (its stylistic, rhetorical features), while Munby analyses the personal, directive and referential functions more closely, particularly with regard to degrees of certainty, commitment, judgement, argument, rational enquiry and exposition. In addition, Munby's indications of the variety of realisations of functions, particularly the formal-informal options available, and his cross references to the important Communicative Grammar of English by Leech and Svartvik, are valuable for language teachers.

Munby's analysis is applied at the end of a profile of needs for the language learner. This profile identifies the learner's role for which the language is needed, the setting, who the interaction will be with, how communication will take place (spoken or written, in dialogue, face to face or by phone and so on), the communicative events, the communicative activities, and the subject matter which must be known.

Using this profile, the teacher is able to select a list of the speech acts which will form the essential communicative knowledge required for the learner's situation. It will not, of course, prepare the learner for unpredicted communicative needs.

\section{PROBLEMS IN THE ANALYSIS OF SPEECH ACTS}

Obvious practical problems present themselves to the teacher who is given a class of pupils who have different needs. This has led to a policy of specialisation in language teaching, whereby pupils are grouped according to their individual communicative needs.

In schools where English is used as the medium of instruction, the catch-phrase, "every teacher is a teacher of English" has led to a policy of Language Across the Curriculum. Teachers of all subjects now recognise that they have a responsibility towards their pupils' linguistic needs.

More specifically, the analysis of speech acts, however exhaustive, cannot predict all the realisations of each speech act. This is because speech acts are often dependent on their social context for successful realisation. For example, the sentence, "I like the scent you are waring" appears to be a compliment. But if that is all that a man says to a woman whom he is dating, it may be both intended and taken as an insult. "What about the rest of me?" she will say to herself. In that context a more sweeping compliment such as, "You look lovely" would be needed.

In addition, sarcasm is usually dependent on context for its choice and interpretation. "You smell wonderful" (to continue the theme of our example) may be an expression of strong approval if the person to whom it is spoken has stepped out of a fragrant bath. On the other hand, it would be a sarcastic comment to someone who has been peeling onions.

Earlier on, a list of ways warning someone against doing something was given. The variety of choices for expressing almost all speech acts is very wide in English. For example, the speech act of telling someone to do something takes the form of a command, but may be expressed in many different ways depending on the degree of authority of the speaker and the formal/informal context of the communicative event. Some expressions may be extremely indirect, given strong shared understandings between speaker and hearer (in the case over the page about tea drinking). 
Such non-explicit illocutionary acts are performed without the use of a performative verb. They are said to have the illocutionary force of the performative verb.

Would you make some tea please?

Make some tea!

Will you put on the kettle?

Are you making some tea?

I think we need a break.

Is it teatime?

What's the time?

How about some tea?

This may not seem particularly important in the context of making a cup of tea. However, it would be important for a servant to grasp the illocutionary force of the utterance. In a more urgent situation, shall we say a nurse approaching a doctor with the words, "The patient's breathing is failing", to which the doctor replies, "I think he should have oxygen", it would be vital for the nurse to realise that the doctor was commanding and not opinioning.

Information structure has important implications for interpreting the illocutionary force of an utterance. For example, the following sentences have the same propositional content, but different intentions:

Because I was unfairly victimised, I resigned.

I resigned because I was unfairly victimised

The first has the illocutionary force of explanation, whereas the second is an assertion. This change is achieved by topicalising first the reason, and secondly the result.

Stress and intonation in English are different from any other languages (Lanham 1984), and play a vital role in the realisation of speech acts. Stress is used pragmatically to draw attention to information which the speaker wishes to emphasise, but it may do more than this. The statement, "The door is open", may, given stress on "is", be an affirmation in reply to a question. However, if someone is looking for the source of a draught and this sentence is spoken with stress on "door", it would be intended as a direction to close the door. Again, realisation of the illocutionary force of the speech act depends on the context of the utterance.

Falling tone, usually assigned to statements and commands, may be used with question forms to give a command or instruction with added emphasis. For example, "Are you going to be quiet?" with a rising tone on the last stressed syllable would require a yes or no reply. However, if "quiet" is assigned a falling tone, the sentence becomes a command to be quiet, but with the added emphasis: "because if you're not going to be quiet, I'll punish you", which would be intended to be taken as a warning or threat. As with a command, this pragmatic use of tone would only be appropriate when spoken by someone in authority (e.g. adult to child) who would enforce the command.

Rising tones, usually assigned to the final stressed syllable of questions or which may be used at the end of tone units to signal incompleteness in a sentence, can be applied to statements to produce a similar effect to a tag-question. It produces the speech act of questioning what another person is doing, often even the motives behind the action. The statement "You're going home", with a rising tone on the final stressed syllable might mean, "I see you're going home. That is unexpected. Please explain." It seems to need more than merely a yes or no answer.

Falling and rising tones may also signal the end or the beginning of a topic line in spoken discourse, which would be important contributions to the "phatic functions" (in Hymes' sense) of English.

Another important aspect of the realisation of speech acts is the use of metaphor. Metaphor is commonly cliché-ridden and possible to interpret unequivocally. "You're beating your head against a brick wall" is clearly a warning not to go on doing something. "That is a feather in your cap" is a compliment praising an achievement as being worthwhile. However, metaphor is subject to constant development and innovation (this does not refer to the mixing of metaphors). "That book is a wastepaper basket" must be interpreted afresh as a condemnation of the book, not that this would be 
difficult to do, but more complex images, such as, "He was a bit of a flamingo" need some thought and background knowledge of the appearance and habits of a flamingo.

Metaphor is profoundly a part of speech acts. Consider for example the expression of obligation, "It's my baby", of disapproval, "I wouldn't touch it with a barge pole", of approval, "You're a gem", or of consent, "I'll go along with that". Each of these requires knowledge of the use of common metaphors in English in order for the speaker's intention to be correctly taken. Mother tongue English speakers share a knowledge of this vast store of allusions, which the second language learner will need to analyse and learn afresh, or else request an explanation in more literal terms from the speaker. The converse of this problem is the pupil's translation of metaphor from his or her mother tongue directly into English. While this may at times result in novel metaphorical imagery, it may also result in "mother tongue interference", failing in translation to communicate the intended message. An example of this is the request in Xhosa for someone to speak plainly which, directly translated, is the command "Hamba ze" ("Go naked").

\section{CONCLUSION}

The identification and analysis of speech acts has led to a greater understanding of communication, and has led to a change from the use of rational to the use of functional criteria for the selection and ordering of items in language syllabi. In effect, this constitutes a complete revolution in language teaching, and it took place in less than two decades. The fact that many speech acts are pragmatically derived has also guided educationalists to develop a communicative methodology in which the context presents a realistic language task for the learner in order to prompt him or her to exploit the available resources of communication.

Pragmatics relies on the learner knowing certain principles or guide lines (not strong enough to be classified as rules) for encoding and interpreting language in context. Examples of the ability to identify sarcasm, to exploit the rules for stress and intonation, and to interpret and use metaphorical language without resorting to translation to and from the mother tongue, have been identified as important pragmatic knowledge. It has been shown that there are many devices to indicate the function of the utterance (explicit speech act), but these may signal either an illocutionary act through which a perlocutionary act is intended and effected, or else an illocutionary act which, in a given context, is intended to perform a different illocutionary act (indirect speech acts).

A language syllabus which attempts to address the question "What do you know when you know a language?" must incorporate functional and pragmatic uses of the grammar of the language. Without these applications, the linguistic systems provide only a potential for communication, leaving a huge gap for the learner to cross unaided.

\section{Referencess}

AKMAJIAN, A., DEMERS, R.A. \& HARNISH, R.M. 1979. Linguistics: An Introduction to Language and Communication. MIT.

AUSTIN, J. 1962. How to do things with words. Harvard University Press.

CORDER, S.P. 1973. Introducing Applied Linguistics. Penguin Education.

HYMES, D. 1968. The Ethnography of Speaking, in Fishman (ed.) Readings in the Sociology.of Language. Mouton.

LANHAM, L. 1984. Stress and Intonation and the Intelligibility of South African Black English. Proceedings of the Third National Conference of the South African Applied Linguistics Association.

LEECH, G. \& SVARTVIK, J. 1975. A Communicative Grammar of English. Longman.

MUNBY, J. 1978. Communicative Syllabus Design. Cambridge University Press. 
SEARLE, J.R. 1969. Speech Acts: An Essay in the Philosophy of Language. Cambridge University Press.

VAN EK, J.A. 1975. Systems Development in Adult Language Learning: The Threshold Level. Strasbourg, Council of Europe.

WILKINS, D.A. 1976. Notional Syllabuses. Oxford University Press. 